Human Mutation

WILEY

\title{
Monozygotic twins discordant for neurofibromatosis type 1 due to a postzygotic NF1 gene mutation
}

\begin{tabular}{|r|l|}
\hline Journal: & Human Mutation \\
\hline Manuscript ID: & humu-2010-0543.R2 \\
\hline Diley - Manuscript type: & Mutation in Brief \\
\hline Author: & 02-Feb-2011 \\
\hline Complete List of Authors: & $\begin{array}{l}\text { Vogt, Julia; University of Ulm, Human Genetics } \\
\text { Kohlhase, Juergen; Center for Human Genetics; University of } \\
\text { Freiburg, Institute for Human Genetics and Anthropology } \\
\text { Kastler, Silvia; University of Ulm, Institute Human } \\
\text { Morlot, Susanne; Praxis für Humangenetik } \\
\text { Kluwe, Lan; University Medical Center Hamburg-Eppendorf, } \\
\text { Maxillofacial Surgery } \\
\text { Mautner, Victor; University Hospital Eppendorf, Maxillofacial } \\
\text { Surgery } \\
\text { Cooper, David; Cardiff University, Institute of Medical Genetics, } \\
\text { College of Medicine } \\
\text { Kehrer-Sawatzki, Hildegard; University of Ulm }\end{array}$ \\
\hline Key Words: & $\begin{array}{l}\text { neurofibromatotis type 1, monozygotic twins, mosaicism, } \\
\text { postzygotic mutation }\end{array}$ \\
\hline
\end{tabular}




\title{
Monozygotic twins discordant for neurofibromatosis type 1 due to a postzygotic NF1 gene mutation
}

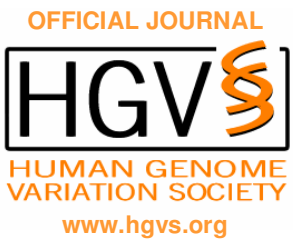

\author{
Julia Vogt ${ }^{1}$, Jürgen Kohlhase², Susanne Morlot ${ }^{3}$, Lan Kluwe ${ }^{4}$, Victor-Felix Mautner ${ }^{4}$, David N. Cooper ${ }^{5}$, Hildegard \\ Kehrer-Sawatzki ${ }^{1}$ \\ 1 Institute of Human Genetics, University of UIm, Ulm, Germany \\ 2 Centre for Human Genetics, Freiburg, Germany \\ 3 Praxis für Humangenetik, MVZ Wagnerstibbe, 30159 Hannover, Germany \\ 4 Department of Maxillofacial Surgery, University Medical Centre, Hamburg-Eppendorf, Germany \\ 5 Institute of Medical Genetics, School of Medicine, Cardiff University, Cardiff, UK
}

${ }^{*}$ Correspondence to Hildegard Kehrer-Sawatzki (hildegard.kehrer-sawatzki@uni-ulm.de), Institute of Human Genetics, University of UIm, Albert-Einstein-Allee 11, 89081 Ulm, Germany,

Contract grant sponsor: Replace this text with the Sponsor Name; Contract grant number: Replace this text with the contract grant number.

Short Title: Monozygotic twins discordant for NF1

Communicated by <Please don't enter>

\begin{abstract}
The analysis of monozygotic twins (MZ) concordant for neurofibromatosis type 1 (NF1) has indicated that genetic factors exert a major influence on the clinical variability (e.g. the number of café-au-lait spots and/or neurofibromas) evident in this disease. Here, we report on a pair of monozygotic, dichorionic twins who are phenotypically discordant with respect to NF1. Whereas DNA sequence analysis indicated somatic mosaicism for the NF1 nonsense mutation, c.4108C > T (p.Q1370X), in the affected twin II/1, this lesion was apparently absent in his unaffected brother. The observation of heterozygosity for flanking SNP and microsatellite markers rendered it most unlikely that the observed mosaicism with normal cells was due to mutation reversion brought about either by gene conversion or mitotic recombination. Instead, we conclude that the twinning event, which would have taken place within three days post-fertilization, must have preceded the c. $4108 \mathrm{C}>\mathrm{T}$ mutation which is therefore predicted to have occurred during the blastocyst stage, leading to somatic mosaicism with normal cells lacking the mutation. This is the first reported case of monozygotic twins discordant for NF1 in whom mosaicism for a postzygotic NF1 gene mutation has been observed in the affected but not the unaffected twin. (02011 Wiley-Liss, Inc.
\end{abstract}

Received <date>; accepted revised manuscript $<$ date $>$.

C) 2011 WILEY-LISS, INC. 
Neurofibromatosis type 1 (NF1; MIM\#162200) is a hereditary cancer predisposition syndrome characterized predominantly by neurocutaneous pathology. The diagnostic hallmarks of the disease are dermal neurofibromas (benign nerve sheath tumours), pigmentation changes such as café-au-lait spots, axillary and inguinal freckling, and Lisch nodules of the iris. Other complications occurring at increased frequency in NF1 include optic gliomas, malignant peripheral nerve sheath tumours, skeletal anomalies and learning difficulties. NF1 is caused by mutations of the NF1 tumour suppressor gene located at 17q11.2. Although NF1 is inherited in simple autosomal dominant fashion with complete penetrance, highly variable clinical expressivity is frequently observed, manifesting as marked inter- and intra-familial variation in relation to the major clinical features of the disease and the co-occurrence of complications [Riccardi, 1992; Friedman et al., 1999].

Monozygotic twins (MZ) with NF1 have been intensively studied as a means to investigate the genetic components of variable expressivity in NF1. A high degree of concordance with respect to clinical symptoms (e.g. café-au-lait spots and neurofibromas) has been observed in many MZ with NF1, suggesting that genetic factors exert a major influence on the inter- and intra-familial clinical variability evident in this disease [Samuelsson and Akesson, 1989; Easton et al., 1993; Huson and Hughes, 1994; Lubinsky, 2006; Payne et al., 2003; Sabbagh et al., 2009; Melean et al., 2010]. In principle, this concordance is readily explicable, not simply in terms of the presence of identical mutations in the MZ, but also as a consequence of the virtual genetic identity of the MZ genome-wide, and their shared experience of very similar pre- and peri-natal environments. Cases of MZ with NF1 who differ quite markedly with respect to the clinical manifestations of the disease have however also been reported [Akesson et al., 1983; Bauer et al., 1988; Kelly et al., 1998; Koul et al., 2000; Detjen et al., 2007] testifying to the likely complexity of the underlying biology. However, the causative mutation has not been identified in such cases and the nature of the factors responsible for bringing about the discordance of clinical symptoms in these MZ twin pairs has remained enigmatic. In this study, we report on a unique pair of monozygotic twins discordant for NF1 in which mutational analysis allowed us to infer the occurrence of a postzygotic $N F 1$ gene mutation exclusively in the affected twin leading to somatic mosaicism for the NF1 mutation.

\section{SUBJECTS AND METHODS}

\section{Clinical evaluation}

The monozygotic male twins were born in May 2007, after an uneventful pregnancy, by spontaneous vaginal delivery to a 28 -year-old mother (gravida-1, para-0) and her nonconsanguineous 30-year-old partner. The attending gynaecologist reported that the monozygotic twins had a dichorionic placenta and were diamniotic. The postnatal course was uneventful. However, clinical investigation at the age of 11 months indicated 7 café-au-lait spots on the trunk of twin II/1 (4 of them being $>5 \mathrm{~mm}$ in diameter). His brother (II/2; Figure 1) did not possess any café-au-lait spots at this age. Inguinal or axillary freckling, Lisch nodules or neurofibromas were observed in neither twin at the age of 11 months. The brothers did not 
differ significantly in terms of the following features: height (both $74 \mathrm{~cm}$ [P25]), weight (twin II/1: $9.3 \mathrm{~kg}$ [P10]; twin II/2: 8.6kg [P10]) and head circumference (twin II/1: $46 \mathrm{~cm}$ [P25-50]; twin II/2: $46.7 \mathrm{~cm}$ [P50]). The presence of 7 café-au-lait spots suggested that twin II/1 might be affected by neurofibromatosis type-1 (NF1), and this was subsequently confirmed by sequence analysis of the NF1 gene when he was 18 months old.

At the age of three years, the twins were reinvestigated clinically. In addition to the caféau-lait spots, patient II/1 had by now also acquired inguinal and axillary freckling. Consequently, the minimum diagnostic criteria for NF1 were fulfilled (i.e. more than 6 café-auspots plus additional NF1-associated symptoms such as axillary and inguinal freckling [National Institutes of Health Consensus Development Conference, 1988]. His brother (II/2) manifested 2 café-au-lait spots at this age, but neither freckling nor other NF1-associated features were apparent. The presence of two café-au-lait spots has been noted in 4.1-6.9\% of healthy white European children [Whitehouse, 1966; McLean and Gallagher, 1995; reviewed by Shah, 2010] and hence cannot be held to be indicative of this individual's NF1 carrier status. Finally, a delay in speech and articulation development was noted in both twins by the investigating clinician (V.-F. M.) but this was not specifically tested.

No neurofibromas, café-au-lait spots, axillary or inguinal freckling, or Lisch nodules were evident in either parent. The patients' parents provided informed consent for the genetic analysis.

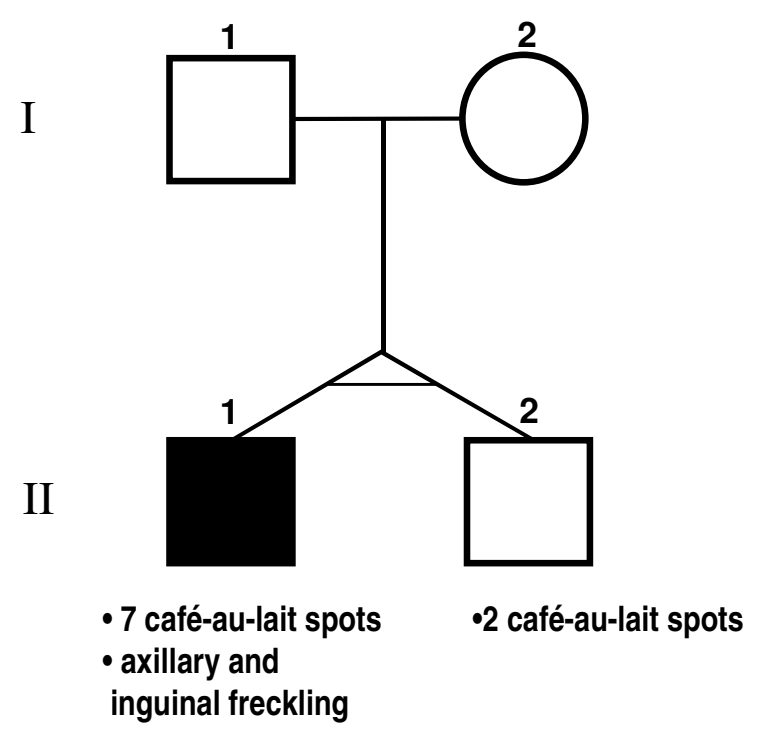

Figure 1

\begin{abstract}
Molecular analysis
Blood samples and buccal swabs were taken from the twins at the age of 11 months and 3 years, respectively. Urine samples were collected from the twins at the age of 3 years. Blood and saliva samples were also obtained from the parents. DNA was isolated from blood and urine samples using the DNeasy Blood and Tissue Kit (Qiagen) and from buccal swabs by means of the NucleoSpin Tissue Kit (Machery-Nagel).
\end{abstract}




\section{Mutation analysis of the NF1 gene}

For mutation identification, the exons included in NFl transcript variant 2 (GenBank accession no. NM_000267.2) were PCR amplified from blood-derived DNA of patient II/1. After clean-up with MultiScreen HTS ${ }^{\mathrm{TM}}$ PCR plates (Millipore), the PCR products were sequenced from both ends on an ABI 3100 DNA Analyzer (Applied Biosystems).

In order to search specifically for the presence of the identified $N F 1$ mutation in the brother and the parents of patient II/1 as well as in samples of his DNA isolated from buccal swabs and urine, $N F 1$ exon 23-2 was PCR amplified using primers Ex23-2for (5' TTTTGTAGGTTAGAACCATCAGAGAG 3' and Ex23-2rev (5' TCAATGTATTATTCATCCAAACTGA 3') and subsequently sequenced as described above.

\section{SNP analysis}

Genotyping of SNP rs7216033 (located 1493-bp centromeric to NF1 cDNA position c.4108C) and rs7220483 (located 1113-bp telomeric to cDNA position c.4108C) was performed by PCR and sequence analysis. Primers used for this analysis were: rs7216033SNP_1for: 5' GGGAGGGGACATCTAGCAG 3' and SNP_1rev: 5'GGGGAGAGAGGGGACAGATA 3' and rs7220483 SNP_2for: 5' AAAGCTGTTTGAGGCTGCTC 3' and SNP_2rev: 5' CTAGGCCAACCAAGAAGCTG 3'.

\section{SNaPshot analysis}

To estimate the proportion of cells with the mutant $N F 1$ allele in the peripheral blood of patient II/1, we performed SNaPshot ${ }^{\mathrm{TM}}$ (Applied Biosystems), a primer extension-based method which makes possible the quantification of differences in the peak heights between two alleles. First, PCRs were performed with the primer combination Ex23-2for/Ex23-2rev on genomic DNA derived from the blood of patient II/1. The resulting PCR products were purified with ExoI/FastAP ${ }^{\mathrm{TM}}$ (Fermentas) for $15 \mathrm{~min}$ at $37^{\circ} \mathrm{C}$ and subsequently heat-inactivated. SNaPshot reactions were then performed with $2 \mathrm{pmol}$ primer $5^{\prime}$ GTGTGTGCCACTGTTTATAC 3', $1.5 \mu$ of the purified PCR products, and $2.5 \mu \mathrm{l}$ SNaPshot master mix (Applied Biosystems). Reactions were carried out at $96^{\circ} \mathrm{C}$ for $10 \mathrm{~s}, 50^{\circ} \mathrm{C}$ for $5 \mathrm{~s}$ and $60^{\circ} \mathrm{C}$ for $30 \mathrm{~s}$, and repeated for a total of 25 cycles. Following cycling, samples were incubated with calf intestinal phosphatase at $37^{\circ} \mathrm{C}$ for $45 \mathrm{~min}$. Samples were then analysed on an ABI 3100 Genetic Analyzer using the GeneScan 6.0 software to determine the relative peak heights of mutant vs normal alleles. The relative proportions of the mutant $N F 1$ allele were then determined by integration of the values into a standard curve.

\section{Multi-allelic marker analysis}

The twins' monozygosity was confirmed by genotyping 15 STR loci distributed across the genome using the AmpF/STR ${ }^{\circledR}$ Identifier System (Applied Biosystems) as well as 15 microsatellite markers on chromosome 17 (listed in Supp. Fig. S1). PCR primers used to analyse the microsatellite markers are available from the authors upon request.

The parental origin of the chromosome 17 on which the NF1 gene mutation occurred in II/1 was determined by microsatellite marker analysis. Haplotypes were reconstructed by 
inference from the marker haplotype of a somatic hybrid cell line carrying only the normal chromosome of patient II/1. This somatic cell hybrid line was generated by the polyethylene glycol-mediated fusion of the thymidine kinase-deficient mouse cell line B82 with lymphoblastoid cells from the patient, with subsequent cultivation of hybrids in selection medium containing hypoxanthine, aminopterin and thymidine.

\section{Cloning of PCR products}

PCR products obtained with the primers Ex23-2for/Ex23-2rev on genomic DNA derived from blood, urine and buccal swabs of the twin brothers were cloned using the StrataClone ${ }^{\mathrm{TM}}$ PCR cloning kit (Agilent Technologies). To determine the proportion of fragments in each PCR reactions harbouring either the mutant or the wild-type allele at NF1 cDNA position c.4108, DNA was isolated from single plasmid clones and analysed by restriction enzyme digestion using BstNI (New England Biolabs) and sequence analysis on an ABI 3100 Genetic Analyzer.

\section{RESULTS}

The analysis of multi-allelic markers confirmed the monozygosity of the twins whilst microsatellite marker analysis of the family members indicated the correctness of assumed paternity (Supp. Fig. S1). Mutation analysis revealed a novel NF1 nonsense mutation in the blood cells of the clinically affected twin II/1 (Fig. 2A). The mutation at cDNA position c.4108C $>$ T (p.Q1370X) is located within exon 23-2 of the NF1 gene according to the historical nomenclature (GenBank accession number: NM_000267.2) and within exon 30 according to NCBI nomenclature. SNaPshot analysis indicated that the mutation is present in $30-40 \%$ of cells in the venous blood of the affected twin II/1. Although the mutation was readily identified in blood cells from patient II/1, it was not detected in his buccal epithelial (Fig. 2B) and uroephithelial cells by Sanger sequencing of whole PCR reactions containing multiple PCR products. This notwithstanding, the cloning of single PCR fragments and their subsequent sequence analysis indicated that $4 \%$ of the PCR fragments from buccal swabs of twin II/1 carried the mutant T-allele (Table 1). Using this cloning assay, the mutation was not however detected in the uroepithelial cells of II/1. We concluded that the affected twin (II/1) must be somatically mosaic for the NF1 mutation. Importantly, the c.4108C > T mutation was not detected in either blood, buccal swabs (Fig. 2C, D) or urine from the unaffected twin (II/2), either by Sanger sequencing of whole PCR reactions or by cloning of single PCR products as summarized in Table 1. The mutation was also not detected in either parent.

Table 1: Relative number of wild-type and mutant alleles carrying the $N F 1$ mutation (c. $4108 \mathrm{C}>\mathrm{T}^{\mathrm{a}}$ ) as determined by cloning PCR products amplified from different tissues of the clinically affected twin II/1 and his unaffected twin brother II/2

\begin{tabular}{l|c|c|c|c|c|c}
\hline & \multicolumn{3}{|c|}{$\begin{array}{c}\mathrm{II} / 1 \\
\text { buccal smear }\end{array}$} & urine & \multicolumn{3}{c}{$\begin{array}{c}\mathrm{II} / 2 \\
\text { blood } \\
\text { buccal smear }\end{array}$} & urine \\
\hline $\begin{array}{l}\text { Number of wild-type } \\
\text { PCR products }\end{array}$ & 32 & 48 & 47 & 50 & 50 & 49 \\
\hline $\begin{array}{l}\text { Number of PCR products } \\
\text { with the mutation }\end{array}$ & 13 & 2 & 0 & 0 & 0 & 0 \\
\hline $\begin{array}{l}\text { Proportion of PCR } \\
\text { products with the }\end{array}$ & 29 & 4 & 0 & 0 & 0 & 0 \\
\hline
\end{tabular}


mutation in \%

a: Nucleotide numbering reflects cDNA numbering with +1 corresponding to the A of the ATG translational initiation codon in the reference sequence.

In seeking an explanation for the mosaicism of the $N F 1$ gene mutation observed in only one of the monozygotic twins, two possible mechanisms were considered (schematically drawn in Figure 3). First, the c.4108C $>$ T mutation could have occurred postzygotically, after the twinning event, and only in twin II/1, leading to somatic mosaicism for the mutation (Fig. 3A). In this scenario, since the twins were dichorionic, the twinning event must have taken place within 3 days of fertilisation, during the pre-morula stage [reviewed by Scott, 2002; Nikkels et al., 2008]. An alternative scenario that could in principle also account for the observed mosaicism would be if the zygote had already harboured the mutation, and normal cells lacking the mutation would subsequently have arisen by either gene conversion or mitotic recombination (Fig. 3B). This reversion of the mutation to wild-type would have had to have preceded the twinning event. That mosaicism for the mutation was observed only in the affected twin (II/1) and not in his brother (II/2) would then be explicable in terms of the unequal allocation of mutation-harbouring cells into the two embryos during the process of splitting/twinning.

To distinguish between these two mechanisms, we analysed the phase of two intronic SNPs, rs7216033 and rs7220483. These SNPs are located 1493-bp proximal and 1113-bp distal to the site of mutation (at the genomic DNA level), respectively. These are the only polymorphic variants listed in HapMap (http://hapmap.ncbi.nlm.nih.gov/cgiperl/gbrowse/hapmap28_B36/; public data release \#28) that occur in the vicinity of the mutation and which could be used to assess local heterozygosity. The phase of the SNP alleles with respect to the mutant c.4108 T-allele was determined by PCR (Supp. Fig. S2). Since heterozygosity for both SNPs was observed in the blood cells of both twins, a gene conversion event encompassing the region tagged by these SNP markers would appear to be highly unlikely. However, we cannot unequivocally exclude the occurrence of a mutation-reversing gene conversion event that encompassed a shorter region, spanning the site of mutation but neither of the flanking SNPs. Mitotic recombination, encompassing the NF1 gene and the extended regions located distal to it, could in principle also have caused a reversion of the mutation (as schematically indicated in Fig. 3B). However, microsatellite marker analysis revealed heterozygosity distal to the NF1 gene in the blood of both twins (Supp. Fig. S1). This observation, in addition to the observed heterozygosity for the flanking SNPs rs7216033 and rs7220483 renders mitotic recombination unlikely as a mechanism leading to reversion of the mutation, since mitotic recombination would be expected to have generated an extended region of homozygosity encompassing several Mb flanking the mutation. Taken together, our findings strongly suggest that the most likely explanation for the presence of the NF1 gene mutation in twin II/1 but not in his brother was that this lesion occurred during the postzygotic cell divisions after the twinning event, leading to somatic mosaicism for the mutation in II/1.

Microsatellite marker and SNP analysis of blood samples derived from patient II/1 and his relatives, as well as DNA isolated from somatic cell hybrids carrying only the normal 
chromosome of patient II/1, indicated that the mutation must have occurred on the chromosome 17 inherited from the twin's mother, I/2 (Supp. Fig. S1).

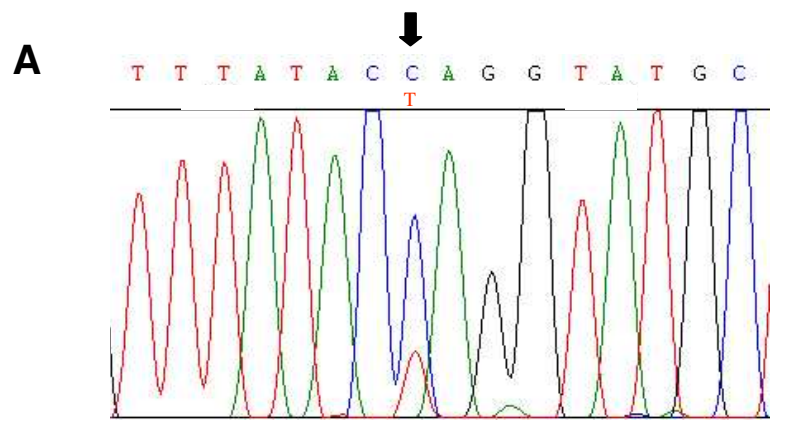

II/1, blood, c.4108 C>T

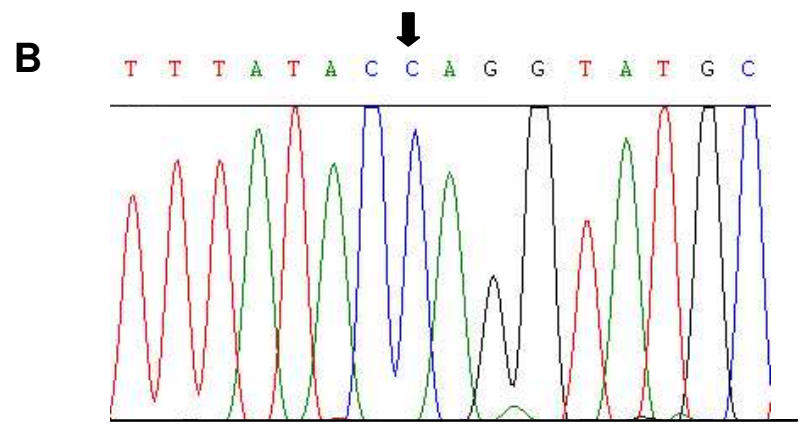

II/1, buccal mucosa
$\begin{array}{llllllllllllllllllllllll}\mathbf{C} & & T & T & T & A & T & A & C & C & A & G & G & T & A & T & G & C\end{array}$

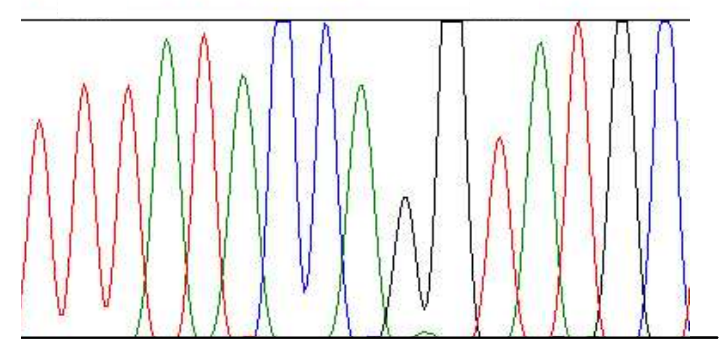

III/2, blood
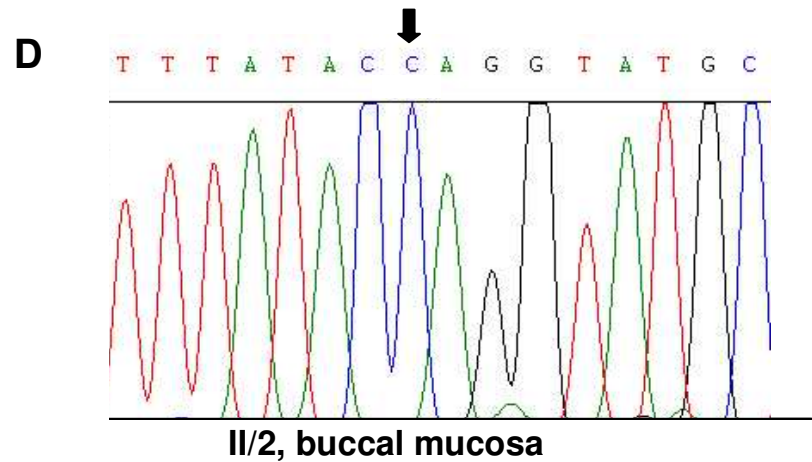

Figure 2

John Wiley \& Sons, Inc. 

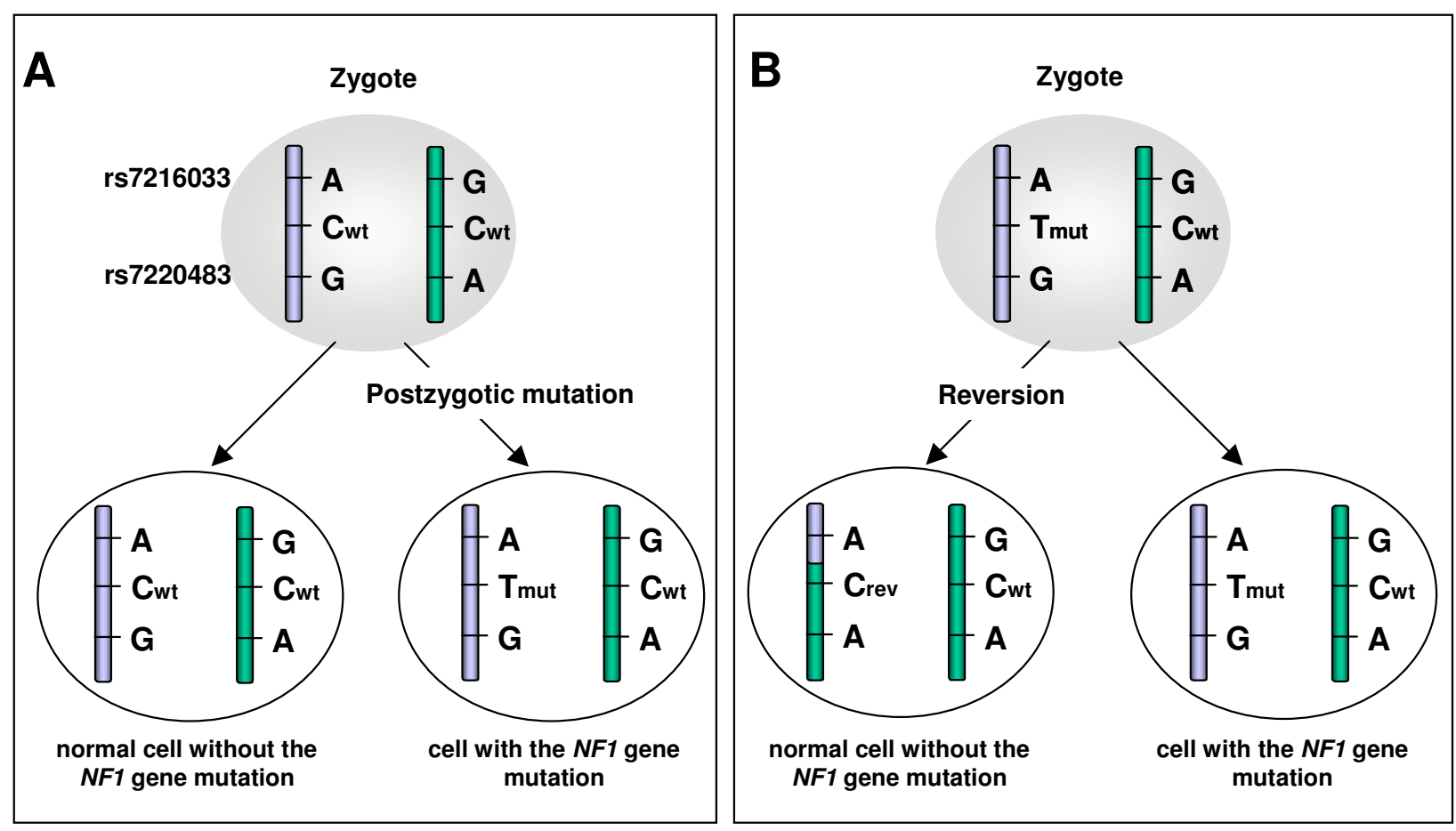

Figure 3

\section{DISCUSSION}

Monozygotic twins (MZ) are generally considered to represent the epitomy of interindividual identity. However, the unequal allocation of blastomeres to the MZ inner cell mass during the twinning event, lateral asymmetry, differences experienced in the pre- and peri-natal environments, and the consequences of intra-uterine twin-to-twin blood transfusion, all have the potential to give rise to phenotypic differences between MZ [reviewed by Machin et al., 2009]. Further, it is increasingly recognized that molecular mechanisms such as skewed Xinactivation, newly acquired epigenetic differences, mosaicism for chromosomal aberrations and postzygotic gene mutations may also result in phenotypic discordance for monogenic disorders in MZ [reviewed by Machin et al., 2006, 2009; Baranzini et al., 2010; Ollikainen et al., 2010; Rijntjes-Jacobs et al., 2010].

It is clear that the timing of postzygotic gene mutation can have a very considerable impact on the discordance of clinical symptoms between MZ. Recently, an intriguing case of phenotypic discordance in MZ, resulting from a postzygotic gene mutation in the SCN1A gene [MIM\#182389] causing Dravet's syndrome, was reported by Vadlamudi et al. [2010]. In this remarkable case, an unusually precise assessment of the timing of the postzygotic mutation proved possible. A truncating mutation c. $664 \mathrm{C} \rightarrow \mathrm{T}$ in exon 5 within the SCN1A gene was identified in the clinically affected girl but not in her unaffected monozygotic twin sister. However, neither twin displayed any evidence for mosaicism with respect to cells either 
harbouring or lacking this mutation. Consequently, the respective mutation must have occurred in the pre-morula embryo stage, and most likely at the two-cell stage post-fertilization prior to the twinning event that gave rise to two distinct embryos differing genetically in terms of the presence or absence of the SCN1A mutation [Vadlamudi et al., 2010].

Postzygotic gene mutations occurring during later stages of embryonic development can also cause phenotypic discordance for single gene disorders in MZ. In these cases, however, mosaicism with normal cells can play a key role as exemplified by the case of the MZ reported here. We identified mosaicism for the mutation c.4108C $>\mathrm{T}$ (p.Q1370X), located in exon 23-2 of the NF1 gene, in the affected twin II/1 but not in his unaffected twin brother (Fig. 1 and 2). These twins were dichorionic and diamniotic. This type of pregnancy arises when the splitting event, which gives rise to the twin embryos, occurs early (within three days of fertilization) before the inner cell mass and the trophectoderm have formed [reviewed by Scott, 2002; Nikkels et al., 2008]. On the basis of SNP and microsatellite marker analyses, we were able to deduce that the mutation c.4108C $>\mathrm{T}$ is likely to have occurred after the twinning event (and hence after the third day of embryonic development), leading to mosaicism for the mutation in only one of the twins (Figure 4).

In contrast to the discordant MZ described here, a second example of MZ discordant for NF1 reported by Kaplan et al. [2010] were found to be monochorionic and diamniotic. A heterozygous truncating NF1 gene mutation [R1968X according to NF1 transcript variant 1 (NM_001042492.2) or R1947X according to NF1 transcript variant 2 (NM_000267)] was identified in all cells from the affected twin, whereas mosaicism involving normal cells and cells harbouring the mutation was detected in the unaffected twin. Owing to the monochorionic nature of these twins, the NF1 mutation is likely to have preceded the twinning event, which supposedly occurred between 4 and 8 days post-fertilization (Figure 4). MZ arise if the twinning event occurs after the formation of the two cell layers, the inner cell mass and the trophectoderm, at the early blastocyst stage of embryogenesis [reviewed by Scott, 2002; Nikkels et al., 2008]. When the molecular findings in the MZ reported by Kaplan et al., [2010] are taken together with those described here, it is clear that the relative timing of the postzygotic mutation and twinning events can exert a major influence on the extent of the subsequent phenotypic discordance in MZ (Figure 4).

It is well known that mosaicism due to postzygotic gene mutation can have a major impact on variable expressivity in many monogenic disorders including NF1 [reviewed by Youssoufian and Pyeritz, 2002; Kehrer-Sawatzki and Cooper, 2008; Erickson, 2010]. Mosaic NF1 microdeletions, which include the NF1 gene and its flanking regions, are frequently associated with a relatively mild disease phenotype [Petek et al., 2003; Kehrer-Sawatzki et al., 2004; Maertens et al., 2007; Steinmann et al., 2007; Roehl et al., 2010] whereas patients with germline NF1 microdeletions are often severely affected, with for example a high tumour burden [DeRaedt et al., 2003; Mensink et al., 2004; Venturin et al., 2004; Pasmant et al., 2010; Mautner et al., 2010]. Although only a relatively small number of cases of mosaic intragenic NF1 mutations have so far been identified [Consoli et al., 2005; Maertens et al., 2007; Bottillo et al., 2010; Muram-Zborovski et al., 2010], we may nevertheless surmise that postzygotic NF1 mutations leading to mosaicism are associated with a wide spectrum of clinical phenotypes including a mild generalized form of NF1 (with NF1 symptoms that are not restricted to specific regions of the body) or segmental NF1, where disease symptoms such as neurofibromas and pigmentary changes are confined to a few body segments [reviewed by Ruggieri and Huson, 2001; Kehrer-Sawatzki and Cooper, 2008; Messiaen et al., 2011]. At the 
extreme end of the spectrum of phenotypic variability associated with mosaicism for an NF1 gene mutation is the complete absence of NF1-associated features as documented by the unaffected 57-year old twin sister of the phenotypically discordant MZ reported by Kaplan et al., [2010]. Remarkably, even at that age, the unaffected twin with mosaicism for the NF1 gene mutation did not display any disease features. We may surmise that, in those tissues of this unaffected twin that are normally affected by NF1 disease features, the proportion of cells harbouring the NF1 mutation is likely to be very low, presumably occurring in insufficient number to give rise to clinically overt NF1.

In contrast to the middle-aged MZ reported by Kaplan et al. [2010], the twins described here were only three years old. Although the c.4108C $>$ T mutation was not identified in blood, buccal and bladder epithelial cells of the unaffected twin, we cannot unequivocally exclude the possibility that the mutation could be present in only a small subset of cells in his body and that he may also come to develop clinical symptoms of NF1 later in life. If this indeed turns out to be the case, and both $\mathrm{MZ}$ reported here are shown to exhibit mosaicism, then we would be able to infer that the NF1 mutation had occurred before the twinning event (within the first 3 days post-fertilization), at a stage when the embryo comprises only 2-16 cells. The marked difference in the number of cells harbouring the mutation between the MZ would then in principle be explicable in terms of the different allocation of normal vs. mutated cells to the two pre-morulae and/or subsequent unequal proliferation of normal vs. mutated cells. Since placental anastomoses that can give rise to twin-twin blood transfusion are extremely rare in dichorionic placentas [Ramos-Arroyo et al., 1988; French et al., 1998; Foschini et al., 2003], blood exchange between the twins is most unlikely to have influenced the proportions of normal vs. mutated cells in the twins described here. Although gene conversion and mitotic recombination have both been shown to be capable of causing mutation reversion [and hence somatic mosaicism in other monogenic disorders; Choate et al., 2010], the heterozygosity observed for two SNPs flanking the c.4108C $>$ T mutation identified in the affected twin (II/1) renders it unlikely that either gene conversion or mitotic recombination gave rise to the mosaicism via mutation reversion in this particular case (Fig. 3). Therefore, the most likely scenario is that the $\mathrm{c} .4108 \mathrm{C}>\mathrm{T}$ mutation occurred during postzygotic cell divisions, leading to the presence of somatic mosaicism with normal cells lacking the mutation. Irrespective of whether or not twin II/2 harbours the c. $4108 \mathrm{C}>\mathrm{T}$ mutation in a small subset of his body cells, mosaicism for this postzygotic NF1 gene mutation appears to be responsible for the observed phenotypic discordance of NF1 clinical symptoms in the twins described here. Hence, our study serves to emphasize the point that genetic factors can exert a major influence on the clinical inter- and intra-familial variability evident in NF1. 


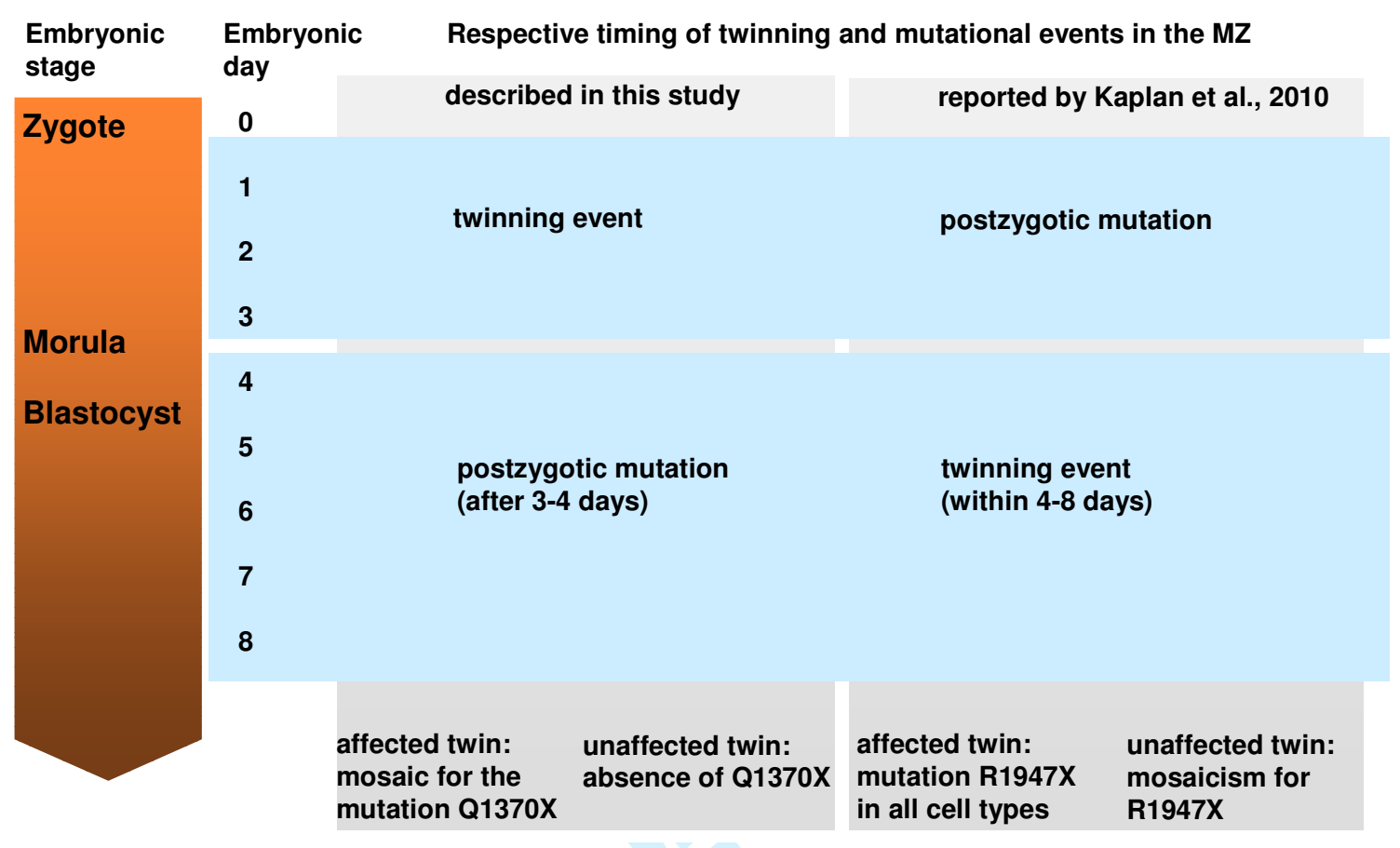

Figure 4

\section{ACKNOWLEDGEMENTS}

We are most grateful to Ludwine Messiaen for her insightful suggestions in relation to the manuscript, and to Helene Spöri and Sigrid Wieland-Lange for their technical support. This work was supported by the Deutsche Krebshilfe (grant \#108793, H.K.-S.; V.-F.M.). J. V. holds a fellowship from the International Graduate School in Molecular Medicine, Ulm.

\section{REFERENCES}

Akesson HO, Axelsson R, Samuelsson B. 1983. Neurofibromatosis in monozygotic twins: a case report. Acta Genet Med Gemellol (Roma) 32:245-249.

Baranzini SE, Mudge J, van Velkinburgh JC, Khankhanian P, Khrebtukova I, Miller NA, Zhang L, Farmer AD, Bell CJ, Kim RW, May GD, Woodward JE, Caillier SJ, McElroy JP, Gomez R, Pando MJ, Clendenen LE, Ganusova EE, Schilkey FD, Ramaraj T, Khan OA, Huntley JJ, Luo S, Kwok PY, Wu TD, Schroth GP, Oksenberg JR, Hauser SL, Kingsmore SF. 2010. Genome, epigenome and RNA sequences of monozygotic twins discordant for multiple sclerosis. Nature 464:1351-1356.

Bauer M, Lubs H, Lubs ML. 1988. Variable expressivity of neurofibromatosis-1 in identical twins. Neurofibromatosis 1:323329. 


\section{$12<$ First Author et al.>}

Bottillo I, Torrente I, Lanari V, Pinna V, Giustini S, Divona L, De Luca A, Dallapiccola B. 2010. Germline mosaicism in neurofibromatosis type 1 due to a paternally derived multi-exon deletion. Am J Med Genet A 152A:1467-1473.

Choate KA, Lu Y, Zhou J, Choi M, Elias PM, Farhi A, Nelson-Williams C, Crumrine D, Williams ML, Nopper AJ, Bree A, Milstone LM, Lifton RP. 2010. Mitotic recombination in patients with ichthyosis causes reversion of dominant mutations in KRT10. Science 330:94-97.

Consoli C, Moss C, Green S, Balderson D, Cooper DN, Upadhyaya M. 2005. Gonosomal mosaicism for a nonsense mutation (R1947X) in the NF1 gene in segmental neurofibromatosis type 1. J Invest Dermatol 125:463-466.

Detjen AK, Tinschert S, Kaufmann D, Algermissen B, Nürnberg P, Schuelke M. 2007. Analysis of mitochondrial DNA in discordant monozygotic twins with neurofibromatosis type 1. Twin Res Hum Genet 10:486-495.

De Raedt T, Brems H, Wolkenstein P, Vidaud D, Pilotti S, Perrone F, Mautner V, Frahm S, Sciot R, Legius E. 2003. Elevated risk for MPNST in NF1 microdeletion patients. Am J Hum Genet 72:1288-1292.

Easton DF, Ponder MA, Huson SM, Ponder BA. 1993. An analysis of variation in expression of neurofibromatosis (NF) type 1 (NF1): evidence for modifying genes. Am J Hum Genet 53:305-313.

Erickson RP. 2010. Somatic gene mutation and human disease other than cancer: An update. Mutat Res 705:96-106.

Friedman J.M., Gutmann D.H., MacCollin M., Riccardi V.M. 1999. Neurofibromatosis: Phenotype, Natural History, and Pathogenesis. Baltimore: Johns Hopkins University Press.

French CA, Bieber FR, Bing DH, Genest DR. 1998. Twins, placentas, and genetics: acardiac twinning in a dichorionic, diamniotic, monozygotic twin gestation. Hum Pathol 29:1028-1031.

Foschini MP, Gabrielli L, Dorji T, Kos M, Lazzarotto T, Lanari M, Landini MP. 2003. Vascular anastomoses in dichorionic diamniotic-fused placentas. 1. Int J Gynecol Pathol 22:359-361.

Hall JG, Lopez-Rangel E. 1996. Embryologic development and monozygotic twinning. Acta Genet Med Gemellol (Roma) 45:53-57.

Huson SM, Hughes RAC. 1994. The Neurofibromatoses. A Pathogenetic and Clinical Overview. Chapman and Hall Medical, London

Kaplan L, Foster R, Shen Y, Parry DM, McMaster ML, O'Leary MC, Gusella JF. 2010. Monozygotic twins discordant for neurofibromatosis 1. Am J Med Genet A 152A:601-606.

Kehrer-Sawatzki H, Kluwe L, Sandig C, Kohn M, Wimmer K, Krammer U, Peyrl A, Jenne DE, Hansmann I, Mautner VF. 2004. High frequency of mosaicism among patients with neurofibromatosis type 1 (NF1) with microdeletions caused by somatic recombination of the JJAZ1 gene. Am J Hum Genet 75:410-423.

Kelly TE, Sproul GT, Huerta MG, Rogol AD. 1998: Discordant puberty in monozygotic twin sisters with neurofibromatosis type 1 (NF1). Clin Pediatr (Phila) 37:301-304.

Koul RL, Chacko A, Leven HO. 2000. Dandy-Walker syndrome in association with neurofibromatosis in monozygotic twins. Saudi Med J 21:390-392.

Lubinsky MS. 2006. Non-random associations and vascular fields in neurofibromatosis 1: a pathogenetic hypothesis. Am J Med Genet A 140:2080-2084.

McLean DI, Gallagher RP. 1995. "Sunburn” freckles, café-au-lait macules, and other pigmented lesions of schoolchildren: the Vancouver Mole Study. J Am Acad Dermatol 32:565.

Machin GA. 1996. Some causes of genotypic and phenotypic discordance in monozygotic twin pairs. Am J Med Genet 61:216228.

Machin G. 2009. Non-identical monozygotic twins, intermediate twin types, zygosity testing, and the non-random nature of monozygotic twinning: a review. Am J Med Genet C Semin Med Genet 151C:110-127.

Mautner VF, Kluwe L, Friedrich RE, Roehl AC, Bammert S, Högel J, Spöri H, Cooper DN, Kehrer-Sawatzki H. 2010. Clinical characterisation of 29 neurofibromatosis type-1 patients with molecularly ascertained $1.4 \mathrm{Mb}$ type-1 NF1 deletions. J Med Genet 47:623-630. 
Mensink KA, Ketterling RP, Flynn HC, Knudson RA, Lindor NM, Heese BA, Spinner RJ, Babovic-Vuksanovic D. 2006. Connective tissue dysplasia in five new patients with $N F 1$ microdeletions: further expansion of phenotype and review of the literature. J Med Genet 43:e8.

Maertens O, De Schepper S, Vandesompele J, Brems H, Heyns I, Janssens S, Speleman F, Legius E, Messiaen L. 2007. Molecular dissection of isolated disease features in mosaic neurofibromatosis type 1. Am J Hum Genet 81:243-251.

Melean G, Hernandez AM, Valero MC, Hernandez Imaz E, Martin Y, Hernandez-Chico C. 2010. Monozygotic twins with neurofibromatosis type 1, concordant phenotype and synchronous development of MPNST and metastasis. BMC Cancer 10:407.

Messiaen L, Vogt J, Bengesser K, Fu C, Mikhail F, Serra R, Garcia-Linares C, Cooper DN, Lazaro C, Kehrer-Sawatzki H. 2011. Mosaic type-1 NF1 microdeletions as a cause of both generalized and segmental neurofibromatosis type-1 (NF1). Hum Mutat, in press

Muram-Zborovski TM, Vaughn CP, Viskochil DH, Hanson H, Mao R, Stevenson DA. 2010. NF1 exon 22 analysis of individuals with the clinical diagnosis of neurofibromatosis type 1. Am J Med Genet A 152A:1973-1978.

National Institutes of Health Consensus Development Conference. 1988. Neurofibromatosis conference statement. Arch Neurol 45:575-578.

Nikkels PG, Hack KE, van Gemert MJ. 2008. Pathology of twin placentas with special attention to monochorionic twin placentas. J Clin Pathol 61:1247-1253.

Ollikainen M, Smith KR, Joo EJ, Ng HK, Andronikos R, Novakovic B, Abdul Aziz NK, Carlin JB, Morley R, Saffery R, Craig JM. 2010. DNA methylation analysis of multiple tissues from newborn twins reveals both genetic and intrauterine components to variation in the human neonatal epigenome. Hum Mol Genet 19:4176-4188..

Pasmant E, Sabbagh A, Spurlock G, Laurendeau I, Grillo E, Hamel MJ, Martin L, Barbarot S, Leheup B, Rodriguez D, Lacombe D, Dollfus H, Pasquier L, Isidor B, Ferkal S, Soulier J, Sanson M, Dieux-Coeslier A, Bièche I, Parfait B, Vidaud M, Wolkenstein P, Upadhyaya M, Vidaud D; members of the NF France Network. 2010. NF1 microdeletions in neurofibromatosis type 1: from genotype to phenotype. Hum Mutat 31:E1506-1518.

Payne MS, Nadell JM, Lacassie Y, Tilton AH. 2003. Congenital glaucoma and neurofibromatosis in a monozygotic twin: case report and review of the literature. J Child Neurol 18:504-508.

Petek E, Jenne DE, Smolle J, Binder B, Lasinger W, Windpassinger C, Wagner K, Kroisel P, Kehrer-Sawatzki H. 2003. Mitotic recombination mediated by the $J J A Z I$ (KIAA0160) gene causing somatic mosaicism and a new type of constitutional $N F 1$ microdeletion in two children of a mosaic female with only few manifestations. J Med Genet 40:520-525.

Ramos-Arroyo MA, Ulbright TM, Yu PL, Christian JC. 1988. Twin study: relationship between birth weight, zygosity, placentation, and pathologic placental changes. Acta Genet Med Gemellol (Roma) 37:229-238.

Riccardi VM. 1992. Neurofibromatosis: Phenotype, Natural History and Pathogenesis. Baltimore: Johns Hopkins University Press. p.498.

Rijntjes-Jacobs EG, Lopriore E, Steggerda SJ, Kant SG, Walther FJ. 2010. Discordance for Schimmelpenning-Feuerstein-Mims syndrome in monochorionic twins supports the concept of a postzygotic mutation. Am J Med Genet A 152A:2816-2819.

Roehl AC, Vogt J, Mussotter T, Zickler AN, Spöti H, Högel J, Chuzhanova NA, Wimmer K, Kluwe L, Mautner VF, Cooper DN, Kehrer-Sawatzki H. 2010. Intrachromosomal mitotic nonallelic homologous recombination is the major molecular mechanism underlying type-2 NF1 deletions. Hum Mutat 31:1163-1173.

Ruggieri M, Huson SM. 2001. The clinical and diagnostic implications of mosaicism in the neurofibromatoses. Neurology 56:1433-1443

Sabbagh A, Pasmant E, Laurendeau I, Parfait B, Barbarot S, Guillot B, Combemale P, Ferkal S, Vidaud M, Aubourg P, Vidaud D, Wolkenstein P; Members of the NF France Network. 2009. Unravelling the genetic basis of variable clinical expression in neurofibromatosis 1. Hum Mol Genet 18:2768-2778.

Samuelsson B, Akesson HO. 1989. Neurofibromatosis in Gothenburg, Sweden. IV. Genetic analyses. Neurofibromatosis 2:107115.

Scott L. 2002. The origin of monozygotic twinning. Reprod Biomed Online 5: 276-284. 


\section{$14<$ First Author et al.>}

Shah KN. 2010. The diagnostic and clinical significance of café-au-lait macules. Pediatr Clin North Am 57:1131-1153.

Steinmann K, Cooper DN, Kluwe L, Chuzhanova NA, Senger C, Serra E, Lázaro C, Gilaberte M, Wimmer K, Mautner VF, Kehrer-Sawatzki H. 2007. Type 2 NF1 deletions are highly unusual by virtue of the absence of nonallelic homologous recombination hotspots and an apparent preference for female mitotic recombination. Am J Hum Genet 81:1201-1220.

Vadlamudi L, Dibbens LM, Lawrence KM, Iona X, McMahon JM, Murrell W, Mackay-Sim A, Scheffer IE, Berkovic SF. 2010. Timing of de novo mutagenesis - a twin study of sodium-channel mutations. N Engl J Med 363:1335-1340.

Venturin M, Guarnieri P, Natacci F, Stabile M, Tenconi R, Clementi M, Hernandez C, Thompson P, Upadhyaya M, Larizza L, Riva P. 2004. Mental retardation and cardiovascular malformations in NF1 microdeleted patients point to candidate genes in 17q11.2. J Med Genet 41:35-41.

Whitehouse D. 1966. Diagnostic value of the café-au-lait spot in children. Arch Dis Child 41:316.

Youssoufian H, Pyeritz RE. 2002. Mechanisms and consequences of somatic mosaicism in humans. Nat Rev Genet 3:748-758. 


\section{Position of marker on chromosome $17^{\mathrm{a}}$}

24481596 - 24481738

$24885942-24886214$

25124113 - 25124371

25708122 - 25708291

26497479 - 26497687

26598768

26601374

26641851 - 26642254

$26665007-26665027$

26668420 - 26668626

26673148 - 26673299

$26960942-26961211$

$28038006-28038197$

$29161843-29162110$ 30890423 - 30890752

$31148163-31148318$

33160167 - 33160320
II/1

\begin{tabular}{|c|c|}
\hline 126 & 142 \\
270 & 272 \\
254 & 258 \\
176 & 170 \\
210 & 210 \\
$G$ & $A$ \\
$A$ & $G$ \\
396 & 400 \\
280 & 274 \\
211 & 207 \\
150 & 142 \\
274 & 268 \\
194 & 192 \\
274 & 270 \\
312 & 286 \\
154 & 156 \\
156 & 156 \\
\hline
\end{tabular}

II/2

Hybrid

\begin{tabular}{|c|}
\hline 142 \\
272 \\
258 \\
170 \\
210 \\
$A$ \\
$G$ \\
400 \\
274 \\
207 \\
142 \\
268 \\
192 \\
270 \\
286 \\
156 \\
156 \\
\hline
\end{tabular}

I/1

\begin{tabular}{|c|c|}
\hline \multicolumn{2}{|c|}{ Father } \\
\hline & \\
\hline $\begin{array}{l}120 \\
072\end{array}$ & 126 \\
\hline 272 & 270 \\
\hline 254 & 254 \\
\hline 172 & 176 \\
\hline 210 & 210 \\
\hline A & G \\
\hline G & A \\
\hline 400 & 396 \\
\hline 274 & 280 \\
\hline 207 & 211 \\
\hline 140 & $15 c$ \\
\hline 278 & 274 \\
\hline 174 & 194 \\
\hline 266 & 274 \\
\hline 386 & 312 \\
\hline 156 & 154 \\
\hline 166 & 156 \\
\hline
\end{tabular}

$1 / 2$ Mother

\begin{tabular}{|c|c|}
\hline 126 & 142 \\
270 & 272 \\
254 & 258 \\
176 & 170 \\
210 & 210 \\
$G$ & $A$ \\
$A$ & $G$ \\
396 & 400 \\
280 & 274 \\
211 & 207 \\
150 & 142 \\
274 & 268 \\
194 & 192 \\
274 & 270 \\
312 & 286 \\
154 & 156 \\
156 & 156 \\
\hline
\end{tabular}

\begin{tabular}{|c||c|}
142 & 124 \\
272 & 272 \\
258 & 258 \\
170 & 170 \\
210 & 206 \\
$\mathrm{~A}$ & $\mathrm{G}$ \\
$\mathrm{G}$ & $\mathrm{A}$ \\
400 & 396 \\
274 & 280 \\
207 & 211 \\
142 & 150 \\
268 & 276 \\
192 & 190 \\
270 & 270 \\
286 & 286 \\
156 & 154 \\
156 & 166 \\
\hline
\end{tabular}

Supplementary Figure S1: Microsatellite marker and SNP analysis performed in order to investigate homozygosity vs. heterozygosity telomeric to the NF1 gene and to determine the parental origin of the chromosome on which the c.4108C>T mutation occurred in patient II/1. The hybrid cell line carrying the normal chromosome of patient II/1 was generated by fusion of the thymidine kinase-deficient mouse cell line B82 with lymphoblastoid cells taken from the patient. Markers highlighted in bold type are located within the NF1 gene. Haplotypes were reconstructed by inference from the phase of markers observed in the hybrid cell line derived from patient II/1 (employing the maximum parsimony principle).

a: The genomic position indicates the position of the primers used to PCR amplify the respective microsatellite markers. In the case of the SNPs rs7216033 and rs7220483, the exact positions of the SNPs are indicated. 
$16<$ First Author et al.>

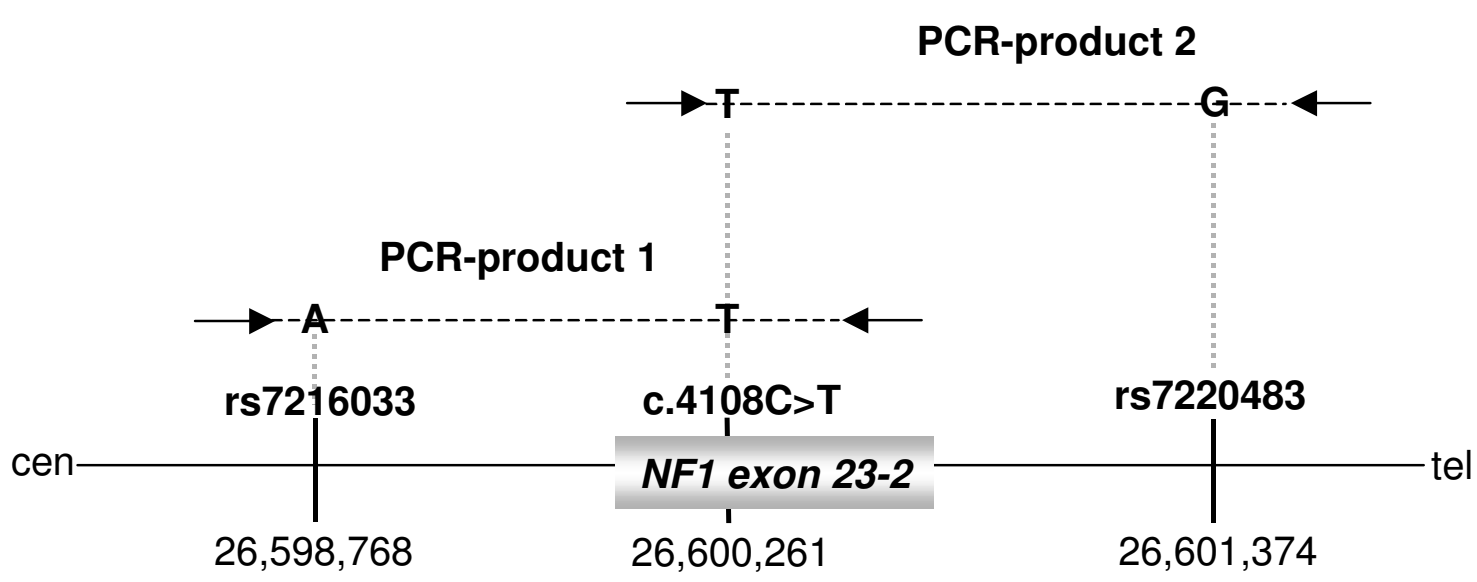

Supplementary Figure S2: Relative locations of SNPs rs7216033 and rs7220483, respectively, 1493 bp centromeric and 1113 bp telomeric to position c.4108 within exon 23-2 of the NF1 gene. The phase of the SNP alleles (in relation to the mutant c.4108 T allele) was determined by PCR using blood-derived DNA from patient II/ 1 as a template followed by sequence analysis of the PCR products. The primers used to amplify PCR products 1 and 2 are indicated by black arrows. 


\section{FIGURE LEGENDS}

Figure 1: Pedigree of the family investigated. NF1 was diagnosed in patient II/1 on the basis that he exhibited 7 café-au-lait spots as well as axillary and inguinal freckling. Although his monozygotic twin brother did not fulfil the diagnostic criteria for NF1, he nevertheless possessed 2 café-au-lait spots.

Figure 2: DNA sequence traces of the NF1 gene mutation, c.4108C >T (p.Q1370X), in the blood of the affected twin II/1 (A). The mutation was not however detected in his buccal mucosa (B) as determined by Sanger sequencing of uncloned PCR products or in blood (C) or buccal swabs (D) from his unaffected twin brother.

Figure 3: Potential mechanisms that could have given rise to mosaicism for the NF1 gene mutation c.4108C $>\mathrm{T}$ in twin II/1. (A) The mutation c.4108C $>\mathrm{T}$ (Tmut) may have occurred postzygotically, subsequent to the twinning event, and exclusively in the affected twin (II/1). The observed heterozygosity of SNPs rs7216033 and rs7220483 (that flank c.4108 in the centromeric and telomeric directions, respectively) is compatible with this explanation. (B) Alternatively, the $N F 1$ gene mutation (c.4108C $>$ T) may already have been present in the zygote prior to the twinning event. In principle, either gene conversion or mitotic recombination could then have been responsible for a reversion of the mutant allele (Tmut) to wild-type $(\mathrm{Crev})$. To investigate whether a large gene conversion event could have been responsible for mutation reversion, SNPs rs7216033 and rs7220483 flanking the NF1 cDNA position c.4108 were analysed. However, heterozygosity for both SNPs was observed in both twins. If mitotic recombination were to have given rise to the mutation reversion, then homozygosity for SNP rs7220483 and for other microsatellite markers located distal to the NF1 gene mutation must be assumed, and this was not observed.

Figure 4: Inferred relative timing of the postzygotic $N F 1$ gene mutations in relation to the monozygotic twinning event in the analysis reported here and that of Kaplan et al., [2010].

Received <date>; accepted revised manuscript $<$ date $>$.

(C) 2011 WILEY-LISS, INC. 